See discussions, stats, and author profiles for this publication at: https://www.researchgate.net/publication/335875979

\title{
The Theory of Common Morality of Bernard Gert
}

Article · August 2019

DOI: $10.26512 /$ rbb.v15i1.26866

\section{CITATIONS}

0

3 authors:

(2)

Flávio Rocha Lima Paranhos

Pontifícia Universidade Católica de Goiás (PUC Goiás)

27 PUBLICATIONS 134 CITATIONS

SEE PROFILE

Jan Helge Solbakk

University of Oslo

79 PUBLICATIONS 633 CITATIONS

SEE PROFILE

Some of the authors of this publication are also working on these related projects:

Persistents Situation in Bioethics View project

Project Conceptual Basis of Bioethics View project
READS

17

Volnei Garrafa

University of Brasília

217 PUBLICATIONS 1,059 CITATIONS

SEE PROFILE 


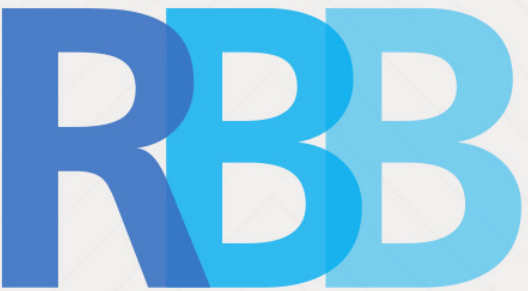

Revista Brasileira de Bioética

Flávio R. L. Paranhos

Escola de Ciências Médicas, Farmacêuticas e Biomédicas da PUC Goiás, Goiânia, Goiás, Brasil

flavioparanhos@uol.com.br

\section{Volnei Garrafa}

Centro Internacional de Bioética

e Humanidades / Cátedra Unesco

de Bioética / Programa de Pós-

Graduação em Bioética da UnB,

Brasília, DF, Brasil

garrafavolnei@gmail.com

\section{Jan Helge Solbakk}

Center for Medical Ethics, Institute of

Health and Society, University of Oslo,

Oslo, Norway

j.h.solbakk@medisin.uio.no

\section{The Theory of Common Morality of Bernard Gert}

\section{A Teoria da Moralidade Comum de Bernard Gert}

Resumo: Tom L. Beauchamp e James F. Childress têm lançado mão de forma crescente de uma teoria moral conhecida como "teoria da moralidade comum" como base filosófica para a sua abordagem de quatro princípios para a ética biomédica, atualmente conhecida como principialismo. $\mathrm{Na}$ última edição (2013) de seus Principles of Biomedical Ethics, os autores reconhecem a contribuição de alguns teóricos anteriores da moralidade comum. Bernard Gert, um crítico do principialismo, é um deles. O objetivo deste artigo é apresentar uma análise crítica da teoria da moralidade comum de Gert, desenvolvida em seu livro Common Morality. Deciding What to Do (2004). de acordo com Gert, a moralidade comum é um sistema moral que todos usam implicitamente ao tomar decisões e julgamentos. Tal sistema consistiria, basicamente, de regras morais, ideais morais e um procedimento de duas etapas usado intuitivamente por cada pessoa para decidir se uma determinada violação de uma regra ou ideal é legítimo. Há dez regras morais, que podem ser agrupadas em duas básicas, a saber, não causar danos (não matar; não cause dor; não desabilite; não privar a liberdade; não privar de prazer), e não violar a confiança (não enganar; manter suas promessas; não trapaciar; obedecer à lei; fazer o seu dever). As regras morais se aplicam aos agentes morais, que são constituídos por todos os seres humanos capazes de compreender plenamente as regras morais, bem como prever as consequências de sua eventual violação. Apesar do apelo intuitivo da abordagem de Gert, bem como de Beauchamp e Childress, a teoria da moralidade comum tem algumas falhas fundamentais que são discutidos no artigo.

Keywords: bioética, fundamentação filosófica, teoria moral, moralidade comum, regras morais, principialismo, Bernard Gert.

Abstract: Tom L. Beauchamp and James F. Childress have been increasingly using a moral theory known as "Theory of Common Morality" as a philosophical basis for their four principle approach to biomedical ethics, currently known as principlism. In the latest edition (2013) of their Principles of Biomedical Ethics, they acknowledge the contribution of some previous theorists of common morality. Bernard Gert, a critic of principlism, is one of them. The aim of this paper is to provide a critical analysis of Gert's Theory of Common Morality, as developed in his book Common Morality. Deciding What to Do (2004). According to Gert, common morality is a moral system that everyone uses implicitly when making decisions and judgments. This system consists, basically, of moral rules, moral ideals and a two-step procedure used intuitively by every person to decide whether a given violation of a rule or ideal is legitimate. There are ten moral rules, which can be collapsed into two basic ones, Do not cause harm (Do not kill; Do not cause pain; Do not disable; Do not deprive of freedom; Do not deprive of pleasure), and Do not violate the trust (Do not deceive; Keep your promises; Do not cheat; Obey the law; Do your duty). Moral rules apply to moral agents, which are constituted by all humans able to fully understand the moral rules, as well as predict the consequences of their eventual violation. It is our understanding that, despite the highly intuitive appeal of Gert's approach, as well as of Beauchamp and Childress's, the Theory of Common Morality has some fundamental flaws which are discussed in the article.

Keywords: bioethics, philosophical grounding, moral theory, common morality, moral rules, principlism, Bernard Gert. 


\section{Introduction}

Since the fourth edition of the Principles of Biomedical Ethics, Beauchamp and Childress have been using, increasingly, a moral theory known as "Theory of Common Morality" (TCM) as a basis for a defense and theoretical underpinning of principlism. In the 7th and latest edition of their book (2013), the authors devote several chapters to the justification of their four principle approach to biomedical ethics. The first and last chapters are particularly devoted to the presentation and development of TCM. In the first chapter of this latest edition the authors recognize that they are not the only ones to avail themselves of such a theory. In a note, they acknowledge that "although there is only one common universal morality, there is more than one theory of common morality" (Beauchamp and Childress 2013, p.25-26).Among the authors cited, one is particularly interesting - Bernard Gert, since he was critic of principlism.

In the last chapter of the same edition, Beauchamp and Childress (2013, p.393397 ) try to elaborate their TCM, when, again, they cite (this time more thoroughly) the ideas of Gert. It is noteworthy, however, that the authors do not disagree fundamentally with the ideas proposed by Gert about TCM, but only with his criticism of their principlism (Beauchamp and Childress 2013, p.394):

Like us, they understand the common morality as universal morality that is not on the cultures, individuals, religions or professional associations. However, Gert and colleagues reject both the language and the substance of our account of principles, while putting forward their own impartial rules and moral ideals as a superior and alternative framework in biomedical ethics.

Later on, the authors turn to the TCM of Gert again, this time to agree with him to the extent that they consider there is no reason why the standards of common morality cannot be justified by a general ethical theory, even though Gert himself has not been able to do this conclusively (Beauchamp and Childress 2013, p.419).

Although Beauchamp \& Childress demonstrate a growing interest in developing a moral theory that might provide an appropriate epistemological foundation for their approach, they fall short of the achievements of Gert. The aim of this paper is to provide a critical analysis of Gert's Theory of Common Morality (TCM), as developed in his book Common Morality. Deciding What to Do (2004). 


\section{On the term "common morality"}

The expression "common morality" may appear with different meanings depending on the chosen approach of different authors, as well as their original intention in using the term. In his book, An Introduction to the Principles of Morals and Legislation, whose first edition was published in 1780, Jeremy Bentham, one of the founding fathers of utilitarianism, presents his proposal of a "principle of utility", which, according to the author, is nothing more than the principle which approves or disapproves of every action that seems to increase or decrease the happiness of those whose interest is in question (Bentham 2007, p.2). Bentham, then, discusses the principles contrary to the principle of utility. These are basically of two types:

asceticism and sympathy/antipathy. While the principle of utility, which Bentham considers an objective one, since it uses a criterion external to the moral agent, the principle of sympathy/antipathy is subjective since it rests only in the disposition to approve or disapprove something (Bentham 2007, p.13-17).

In a footnote to paragraph XIV, concerning the principle of sympathy/antipathy, Bentham refers to the "moral sense" and "common sense". His description of what is "common sense" has some striking similarities with that of Gert's, although the latter has solemnly ignored this line of Bentham's thought (Gert cites Bentham four times, but none of them makes reference to his idea of the morality of common sense):

He then tells you, that his common sense teaches him what is right and wrong (...), meaning, by common sense, a sense of some kind or other, which, he says, is possessed by all mankind. (...) But common sense is as old as the creation; and there is no man but would be ashamed to be thought not to have as much of it as his neighbors. (...) Another comes, and says, that (...) however he has an understanding, which will do quite as well. This understanding, he says, is the standard of right and wrong. (...) If other men's understandings differ in any point from his, so much the worse for them: it is a sure sign they are either defective or corrupt (Bentham 2007, p.17).

In characterizing the principle of sympathy/antipathy (which he refutes), Bentham provides us with a characterization similar to that of Gert's to common morality, but he does not use the expression "common morality". The opposite is the case in a small controversy that arose in the exegetical circles of classical philosophy in the early 
1970s. The question debated was whether the moral theory proposed by Plato was compatible with common morality (Annas 1978, p.437-451). The meaning attributed to the term here is not exactly the same as intended by Gert (2004), as well as by Beauchamp and Childress (2013), although not completely different. The question was whether the morality proposed by Plato, notably in the Republic, particularly book IV, could be approximated to a morality of the ordinary citizen. It is not our aim here to detail this controversy. What is of interest for us is the use of the expression "common morality" as a "morality of ordinary people", which is not the same as that intended by Gert (2004) as well as Beauchamp and Childress (2013), because in this case there would be another parallel morality for an elite.

\section{General characteristics}

According to Gert (2004 p. 3-17), common morality is a moral system that people use implicitly when making decisions and judgments. By "people" he means the whole humanity. Or almost all; i.e. except those who, by age or some severely disabling condition, cannot be considered moral agents (although they continue to be moral persons). Here we have the first nuclear feature of common morality as understood by Gert - an appeal to a universal human nature.

Reason being something inherent in the human nature, it will equally be a prerequisite of the correct application of common morality. Every rational human being will take it into account for their decisions, although it does not mean, according to Gert (2004 p. 3-17), that there will always be agreement. Common morality allows disagreements, and even these are equally legitimate. This is the second nuclear feature in the work of Gert: common morality as a moral framework is flexible. Although a feature of this type is obvious, since no author, with the possible exception of strict Kantians, would propose a system of strict moral norms, it is exactly here, we believe, that the theory of Gert gets into trouble.

The existence of a common morality, or THE common morality, as Gert considers it (and also Beauchamp and Childress) is almost intuitive. It originates from the realization that all people agree tacitly to behave according to unwritten rules accepted by all. For example, "everyone agrees that kill, inflict pain or inability, or even remove the freedom or enjoyment of any other moral agent is immoral, unless there's an appropriate justification for such action" (Gert 2004 p. 9). Similarly, "all moral agents agree that actions such as to save lives, relieve or prevent pain, cure, or prevent disability, and 
prevent the loss of liberty or pleasure are morally good actions, unless by doing them one violates a moral rule" (Gert 2004 p. 9).

Another important feature that also relates to human nature is the recognition of our fallibility and frailty, which forcibly (if we follow Gert) makes us obey the rules of common morality, because we don't want to suffer damage of any kind; so we all observe the rules tacitly accepted for that. It is interesting to note that another different approach to ethics, that of Alasdair Maclntyre (1999), also has this starting point. For the same reason as one may question Maclntyre why any human trait has as a consequence the observance of a particular moral standard, one can question Gert, since this kind of approach suffers from the flaw of every approach that intends to develop the "ought be" from the "is", i.e. the problem of the naturalistic fallacy (Paranhos 2001, p.137-143).

According to Gert (2004, p.13-15), common morality frameworks have four major points of potential disagreement. The first is the question of who deserves consideration of common morality (for example, are fetuses completely covered by the protection of the rules of common morality?). The second point concerns different weighting of different damages suffered by a moral agent (for example, what would be worse, death or permanent coma?). The third point of potential disagreement relates to the fact that people may estimate differently the harmful consequences of a particular action. And the final point is the existence of different possibilities of interpretation of a particular moral rule.

\section{The moral system of Bernard Gert}

The moral system in which common morality is contained consists, basically, of moral rules, moral ideals and a two-step procedure used intuitively by every person to decide whether a given violation of a rule or ideal is legitimate. We will return to the two-step procedure shortly.

According to Gert (2004, p.19-20), it is part of the system of common morality that there is room for disagreement. In other words, although universal, these rules are not necessarily universally accepted or always observed. Here is the list of Gert's ten rules, organized into two halves:

1- Do not kill.

2- Do not cause pain.

3- Do not disable.
6- Do not deceive.

7- Keep your promises.

8- Do not cheat. 
4- Do not deprive of freedom.

5- Do not deprive of pleasure.
9- Obey the law.

10- Do your duty.

The first five rules, says Gert (2004, p.20-21), may be "collapsed into one": Do not cause harm, while the next five can be reduced to: Do not violate the trust. The ten- number choice is, according to Gert, advantageous both for organizational and strategic reasons $(2004$, p.22):

Having ten moral rules, as this formulation does, takes advantage of a well-known tradition. That putting forward exactly ten rules leads some philosophers to try that much harder to find mistakes is an unintended "bonus". The present formulation also results in rules being neatly divided into two distinct categories, the first five prohibiting directly those kinds of actions that causes all the basic harms and the second five prohibiting those kinds of actions that indirectly cause these same harms.

Moral ideals are not specified by Gert, for he considers them obvious. They are weaker than moral rules, since unlike the case of rules, people do not necessarily have to follow the ideals. Do not cause pain, a moral rule, becomes, in a weaker language the moral ideal Prevent avoidable pain. The first is an obligation, the second is not, unless the moral ideal in question is part of the professional duties of the moral agent. For example, the moral ideal, Prevent avoidable pain, is a moral obligation for healthcare workers. If healthcare workers do not prevent avoidable pain, they will be violating the moral rule, Do your duty (Gert 2004, p.22-23).

At this point it might be worth interrupting the presentation of Gert's moral system to address some relevant criticism from Beauchamp and Childress (2013, p.196-397). They refer to Gert's underestimation of moral ideals in the face of moral rules.

Gert commits a mistake, they claim, by considering the principle of beneficence to be "just" an ideal, therefore "less than" a rule, therefore not mandatory. Such a mistake does not only represent an error of judgment (beneficence as not deserving the status of a moral rule), but is as well inconsistent within Gert's own system, because in a

biomedical ethics system beneficence is a duty, therefore mandatory, therefore a rule, not just an ideal.

A stronger criticism, although not directed specifically at Gert, relates to him to the extent that it concerns the role of moral ideals. We refer to the proposal for a radical 
change of perspective, a Latin American approach to Bioethics known as the Bioethics of Intervention (Garrafa and Porto 2003, 399-416). For such a perspective, terms and expressions such as "responsibility; caution; solidarity; commitment; otherness; tolerance; prevention of damage; precaution against the unknown; prudence with respect to new technologies; and protection of social excluded, the most fragile and unassisted" (Garrafa 2005), a list that Gert would classify as moral ideals (with the exception of harm prevention) - and, therefore, not required - become categorical imperatives.

\section{The ten moral rules}

Don't kill. This rule should be interpreted as "do not cause permanent loss of consciousness" because, unless someone has some kind of religious belief that endorses the idea that even without conscience (permanently) a human being is alive, the rule "Do not kill" applies to cases in which the harm suffered does not result in death. But this is not the same as causing loss of consciousness temporarily, which would comply with the moral rule "Do not disable" (Gert 2004, p.29-30).

Do not cause pain. In general, every rational person does not want to experience pain, although there are cases in which, even keeping his rationality, one may wish to feel pain or an unpleasant feeling. For example, riding a roller coaster or see a horror movie (Gert 2004, p.31-32).

Do not disable. Blinding a person or cutting his arm off would be clear examples of violating this moral rule. Likewise, to provide drugs, licit or not, would be mental and volitional examples of such forms of violation (Gert 2004, p.34).

Do not deprive of freedom. Loss of freedom caused by a handicap which was a consequence of the violation of the preceding rule (for example, someone blinded as a consequence of someone else's harmful action would originally be a case of a violation of the rule "Do not disable" or even "Do not cause pain"). Coercion can be regarded as a violation of this rule as can discrimination (e.g. in the selection for a job) (Gert 2004, p.35-38).

Do not deprive of pleasure. Stop scratching someone's back does not characterize as a violation of this rule, but to take away somebody's ice cream does. With respect specifically to this point, as if apologizing for his formulation of moral rules, Gert justifies himself for the "apparent" repetition of rules, insisting on its role in the name of clarity and aesthetics of his "neat" ten-rule formulation (Gert 2004, p.29- 38-39). 
Do not deceive. Gert believes that this formulation is more appropriate than the more common "Do not lie", because intending to deceive by telling a lie is just a way of deceiving among many others. And even if someone is not sure if he or she is deceiving (for example, when helping spreading a rumor), he or she will be breaking this rule (Gert 2004, p.40-41).

Keep your promises. This is the first of the ten rules that is not formulated as a prohibition. But it could be: "Do not break your promises." This affirmative version has the advantage of stressing something that has already been pledged and should not be disrespected (Gert 2004, p.42-44).

Do not cheat. This should not, according to Gert, be seen as just another way of saying "Do not lie" or "Do not deceive" or "Keep your promises". Cheating does not always involve deceiving as, for example, in the case of a boss who cheats in a game not bothering to hide his action because he knows his employees will not complain (Gert 2004, p.44-45).

Obey the law. Even if we consider that there might be unjust laws (discriminatory laws, for example), most laws will be good and fair, and obeying them is seen by all as morally commendable. The difference between a moral system and a legal system is that the first is not expected to solve all cases, while the second is. A moral system is under no obligation to give a definite and unanimous answer. A legal system, no matter how bad the decision may be, has the duty to provide the final answer to a dilemma (Gert 2004, p.47-49).

Do your duty. Included here are cases of professional and parental obligations as well as circumstantial issues. In the latter case, however, Gert makes a differentiation. If someone is circumstantially in a position to help others (saving from drowning, for example), an action is required only if the situation will bring negligible risk. In any other situation it will not be a moral rule, but only a moral ideal, therefore not an obligation (Gert 2004, p.50-53).

\section{To whom do the moral rules apply?}

Moral rules apply to moral agents, which are all humans able to fully understand the moral rules, as well as predict the consequences of their eventual violation.

Therefore, non-human animals, children and people with disabling mental problems cannot be moral agents. This does not mean, however, that they are not entitled 
to the protection afforded by the moral rules. Being a moral agent implies being fully accountable for one's actions. A moral agent can be judged morally. It makes no sense to morally judge a 'non-moral agent' (Gert 2004, p.26-29). At first sight, it seems to exist a clear border between those who are covered by the protection afforded by the moral rules and those who are not. But that is certainly not the case. A fetus, for example, at which point does it deserve the consideration of moral rules? And what about animals? Do they all deserve the same consideration (from bacteria to chimpanzees)? Only those closest to man? Only the most intelligent? Such issues are persistent dilemmas of ethics and the moral system of Gert does not intend to solve them. This, in itself, is, however, not a flaw of Gert's approach.

The problem starts when, trying to solve the problem of to whom his common morality system applies, Gert gets lost in a labyrinth with no exit possible, very similar, by the way, to the case of Beauchamp and Childress. Beauchamp and Childress (2013, p.416-417), trying to justify their theory of common morality empirically, propose a bizarre experiment. To prove that the common morality exists, it would be necessary to design an experiment whose participants would be drawn from (and only from) people who accepted beforehand the premise that the principles proposed by them are the ground of moral judgment (if not all, at least nonmaleficence). That would be equivalent to test a hypothesis that everyone likes strawberry ice cream picking, as a sample, just people who say they like strawberry ice cream. An obvious selection bias.

Gert does something similar. To be entitled to be considered a moral agent, one not only has to have a minimum of intelligence and maturity to understand the rules of common morality and the ability to foresee the consequences of its violation; one would also have to share certain beliefs allegedly required of all moral agents. Such beliefs would, for example, be the recognition of frailty and fallibility of being human, that no one wants to be dead, or to experience pain, or to be disabled or to be deprived of freedom, etc. In other words, the moral agent in Gert's system is one which accepts beforehand the premises of the proposal for a common morality. But this is a tautology that does not help in any way to answer if there is in fact a common morality, or who qualifies as a moral agent.

Carson Strong (2006, p.44) poses a similar criticism:

In other words, we are to imagine a hypothetical situation in which all fully informed, impartial rational persons, regardless of the time, place, and culture in which they live, are to estimate the consequences. Of 
course, many rational persons would not have any knowledge of, say, twenty-first century American culture or bioethics. So, they would not be estimating all of the actual consequences of the violation being publicly allowed or not allowed today in the United States.

Strong refers to the assessment of the consequences of an action based on cultural issues to characterize it as admissible or not as a moral rule, something that we will analyze next, but his observations regarding the cultural differences are applicable also for the moral system as a whole.

\section{Violating the rules justifiably}

Of course Gert does not deny that each and every one of the moral rules can be violated without, necessarily, being immoral in doing so. What are the acceptable justifications?

Firstly, Gert (2004, p.97) emphasizes the importance that rationality has to his moral theory. Rational will be all that is not unreasonable. According to this line of reasoning, one establishes in advance what is irrational, and what's left will be rational. It will be objectively irrational (irrational independent of a subjective judgment) the intentional action of causing (or increasing the risk of) death, pain, disability, etc., for no objective reason. And what would an adequate objective reason be? Any reason which is considered as such by a significant group of people would qualify as an adequate objective reason. Gert $(2004, p .113)$ is explicit about this quantitative detail of his theory:

If only one person would advocate to people for whom he cares that they do some self-harming action for the reason under consideration, that person is not regarded as a rational person. If only a very small number of people would advocate to people for whom they care that they do some self-harming action for the reason under consideration that small number of people are also not regarded as rational. However, any reason that any significant number of otherwise rational people appraises as adequate is objectively adequate.

This excerpt makes it not unreasonable to recall historical examples of deeply immoral actions which were endorsed by a significant number of people, such as the case of the Tuskegee study and, of course, the horrible medical crimes committed in 
concentration camps by the Nazi regime during World War II. Hannah Arendt's (2003, p.118) analysis of the so called 'Eichmann Case' provides us with a relevant remark in relation to this matter: "Morality fell apart and became a mere set of costumes, usages, conventions to be interchanged at will among criminals, but also among ordinary people, since moral standards were socially accepted."

Gert also refers to Nazism, though from another perspective; i.e. not exactly to Nazism, but to nationalism, to exemplify that it is not necessarily so that the worst moral acts come from selfishness, but rather from actions justified by racism, religion and nationalism. But viewed from his line of argument, such actions would be rationally allowed. Here we seem to be left facing a bizarre paradox. That is, Gert is being consistent when considering such situations as "rational", because, after all, they are endorsed by a significant number of people ". But they are, at the same time, undoubtedly morally wrong actions. How can it be?

The solution proposed by Gert (2004, p.123) is the impartiality test. It's not enough to be rational, not even objectively rational (as we have seen); one must also be impartial:

The way in which a person demonstrates this impartiality is by violating a rule only if she would be willing for everyone to know that they are allowed to violate that rule in these same circumstances. She would be willing for everyone to know this only if she estimated that better consequences would result if everyone knew this than if everyone knew they were not allowed to violate the rule in those circumstances.

This excerpt of Gert's book bears some resemblance with the Kantian categorical imperative (Kant 1999, p.42): "Act in such a way that the maxim of your will can always count and at the same time as the principle of a universal law." However, unlike Kant, the nonconsequencialist par excellence, Gert is explicit with respect to the consequences of the action.

That a universalizing condition is applied to a universalizing moral such as the common morality is not exactly a surprise. It is indeed a clever inversion of the story of the ring of Gyges, narrated by Glaucon in book II of the Republic of Plato (359-a and $360 \mathrm{a}-\mathrm{d}$ ), used to demonstrate that people will act ethically only if they believe they are being observed (or if the risk of being caught is big).

At first sight, this makes sense. If I do not care that everyone knows, my violation of the rule is justified. If we look closer, however, it is not difficult to find out the flaws of 
such a criterion. Firstly, who's "everyone"? We already know, and Gert himself realizes this, that this word is not to be taken in its literal sense. He recalls, appropriately, that no one is impartial in isolation, but impartial in relation to someone else. There is no such thing as "universal impartiality". Secondly, there is always the possibility of existing people who are rational, but do not care if others find out about their immoral actions, because they are in a privileged position (as Plato's Thrasymachus very appropriately points out in book I of The Republic, 344 b-c) and Gert (2004, p.83) himself recognizes.

Another problem, also recognized by Gert, is the difference in assigning a value to the harms caused by a certain rule violation, as well as in the estimation of the possible damage. Someone may violate a rule - for example, do not cause pain - predicting that the consequence of this violation will be not as bad as obeying the rule. This brings us back to the criticism of Carson Strong, cited earlier. Strong makes use of some cases to demonstrate how Gert's theory of common morality fails when applied to biomedical ethics. According to Gert, if a physical therapist forces a patient to carry out all the post-stroke rehabilitation sessions, this paternalistic attitude would be wrong, because this healthcare worker would be violating the rule "Do not cause pain".

According to Strong (2006, p.46), this attitude may be considered ethically justified, among other reasons, because the patient has his autonomy impaired, and, if not stimulated (even forced) to finish the treatment, the patient may suffer greater damage than if he is allowed to interrupt it.

Beauchamp and Childress (2013, p.397) made a similar criticism, exemplifying with a case of a patient who, after an accident, while still conscious, expresses the desire not to undergo blood transfusion. Then the patient loses consciousness. The chances for his survival are small, but larger if he is submitted to the transfusion. If the physician performs a transfusion he will be violating the rule "Don't cause pain" (in this case, existential or psychological pain) in Gert's common morality. The physician decides to perform a transfusion, thus saving the patient's life. In this case two possibilities arise: If the physician tells the patient, he will cause psychological pain. If he does not, he will be deceiving the patient. But if the patient dies anyway, the physician did nothing wrong, according to Gert, for he neither caused pain, nor deceived the patient. An odd situation, according to Beauchamp \& Childress, and clearly a violation of the principle of autonomy. 


\section{Final considerations}

Common morality has great appeal in ethical and bioethical approaches of Anglo-American origin. Not only the most widely known approach of all, that of Beauchamp and Childress, but many others, as one can see by the list given by the authors of Principles of Biomedical Ethics (2013, p. 25-26), such as Alan Donagan, W.D. Ross, Robert Veach and Bernard Gert, the latter being the focus of this study.

This is understandable, because common morality, as a core framework of rules of conduct tacitly accepted by all people, regardless of where they live, has, in fact, a certain intuitive appeal. And it sounds reasonable, but it is not. We believe we have had the opportunity to show in this critical analysis of the work of Bernard Gert that there are several identifiable problems, even before we enter the field of bioethics. Already in the realm of ethics, there are structural problems, such as: to whom do moral rules apply, since it is impossible that these are applied to all? Also, how is one to justify satisfactorily the inevitable violations of these rules? In addition, the repetitive and almost puerile formulation of Gert's ten rules is in itself extremely impoverished.

And if we take a step further in the direction of biomedical ethics, there are even more evident difficulties for the application of Gert's moral theory. This is already evident in the critique leveled at Gert by Beachamp and Childress, i.e. by an AngloAmerican approach.

The same occurs if we apply a Latin-American approach to bioethics, i.e. an approach which is even more critical of a possibility of a common morality. From this vantage point the proposal for a common morality as an epistemic foundation for bioethics is completely misplaced and anachronistic. A plural society requires a pluralist bioethics, something with which the proposal for a common morality is incompatible.

\section{References}

1. Annas, J. Plato and the common morality. 1978. The Classical Quarterly (New Series) 28 (2): 437-451.

2. Arendt, H. 2003. Responsabilidade e julgamento. São Paulo, SP: Companhia das Letras.

3. Bentham, J. 2007 (reprint of 1907 Edition). An Introduction to the Principles of Morals and Legislation. Mineola NY: Dover Publications, Inc.

4. Beauchamp, T.L. and Childress, J.F. 2013. Principles of Biomedical Ethics. New York, NY: Oxford University Press. 
5. Garrafa, V. and Porto, D. 2003. Intervention Bioethics: A Proposal for Peripheral Countries in a Context of Power and Injustice. Bioethics 17: 399-416.

6. Garrafa, V. 2005. De uma bioética de princípios a uma bioética interventiva. Rev. Bioét.13 (1):125-134.

7. Gert, B. 2004. Common Morality. Deciding What to Do. New York, NY: Oxford University Press.

8. Kant I. 1999. Crítica da razão prática. Lisbon: Edições 70. Plato. 2001. A República. Lisbon: Calouste Gulbekian.

9. Maclntyre, A. 1999. Dependent Rational Animals. Why Human Beings Need the Virtues. Chicago, IL: Open Court.

10. Paranhos FRL. 2001. Resenha de Alasdair Maclntyre's Dependent Rational Animals. Philósophos. Journal of Philosophy of the Federal University of Goiás. 6(1/2): 137-143.

11. Strong C. 2006. Gert 's Moral Theory and its Application to Bioethics Cases. Kennedy Inst Ethics J.16(1):39-58.

Recebido: 05/02/2019. Aprovado: 15/04/2019. 